\title{
Agile Methods to Increase Teacher Creativity through Knowledge Sharing at South Jakarta
}

\author{
Nur Hikmah \\ Agus Suradika \\ R. Andi Ahmad Gunadi \\ Department of Postgraduate Educational Technology, \\ Faculty of Science Education, \\ University of Muhammadiyah Jakarta
}

\author{
Received: April 4, 2021 \\ Accepted: May 12, 2021 \\ Published: October 1, 2021 \\ Corresponding Author: \\ hikmahnur1168@gmail.com; \\ agus.suradika@umj.ac.id; \\ aagunadi@umj.ac.id \\ DOI: $10.53947 /$ tspj.v1i1.64
}

\begin{abstract}
This study was proposed to examine and analyze the agile method to increase teacher creativity through knowledge sharing which was carried out at 03 Elementary School, Kebayoran Baru, South Jakarta.The background was the gap in the creativity of Computer Information Technology that teachers had in dealing with change. related to government regulations regarding online learning from home. This study uses the agile method which is applied in the world of education with five pillars, namely problem analysis, strategy, action, reflection, results. The strategy used is a knowledge sharing to increase teacher creativity. The method used in this research is descriptive, with a qualitative approach. The analysis technique uses a rating scale, the descriptive method is used to describe the theory used to be applied. From the results of this study, it can be concluded that agile methods can be used in the world of education to cope with very fast changes, and knowledge sharing is the right way to increase teacher creativity.
\end{abstract}

Keywords: Quick Change, Agile Method, Knowledge Sharing, Creativity

\section{Introduction}

The goals of national education as stated in the Law on the National Education System number 20 of 2003, article 3, namely: The development of students to become human beings who believe and fear God Almighty, have a noble character, are healthy, knowledgeable, capable, creative, independent and become democratic and responsible citizens. To realize students who are by the expectations of the law, all education providers must be serious about making programs, implementing and constantly evaluating the program so that it runs according to its objectives and continues to develop according to the conditions of the times. Teachers as the front line in the implementation of education must always be responsible, creative, innovative, and serious in carrying out their duties, to 
achieve what is the goal of education. Teacher creativity is always demanded to realize students as expected in the national education goals. According to Octavia (2014), that, "In the process of learning and teaching, creativity in learning is part of a system that is inseparable from being educated and educators. The role of teacher creativity is not only to help the teaching and learning process by covering only one aspect in humans but includes other aspects, namely cognitive, psychomotor and affective.

Teacher creativity is still according to Octavia in having the main function of helping teachers complete the work of teachers quickly and efficiently. So, according to the researcher, this creativity absolutely must be possessed by a teacher to create students who are following the expectations of the National Education System Law. This creativity must always be encouraged, improved, and developed per the times. Especially in the era of the COVID-19 Pandemic which is currently hitting not only in Indonesia but even all over the world. According to Lowcock in the Kompas daily which was published on July 17, 2020, through an article with the title "COVID-19 for 265 million World Population Threatened with Hunger" stated that, "No one will be safe from this coronavirus". Including Indonesia. One of the efforts to prevent the massive transmission of COVID-19, each country takes a policy by implementing a lockdown or Large-Scale Social Restrictions (PSBB). PSBB itself in Indonesia is regulated in Government Regulation of the Republic of Indonesia Number 21 of 2020 concerning PSBB to deal with COVID-19, namely concerning Large-Scale Social Restrictions in the Context of Accelerating Handling of Corona Virus Disease 2019 (COVIDI9). As a result of the PSBB, a policy has been issued so that all activities are carried out from home, work from home, worship from home, and study from home. The study from home policy began to be implemented on March 16, 2020, after the Minister of Education and Culture issued circulars number 2 of 2020 and number 3 of 2020 regarding online learning (on the network) and working from home to prevent the spread of the Corona Virus.

Even though we cannot meet face to face, learning must be carried out actively, creatively, and innovatively. Online learning or e-learning can bring a new atmosphere in a variety of learning developments. Proper selection and utilization of e-learning can improve learning outcomes to the maximum, (Andayani Dyah Darma et al, 2020). Professional teachers are required to have the ability to increase creativity in the ICT field and be able to apply it in the teaching and learning process (Darmadi, 2016). Online learning or e-learning using online media is very diverse and the proliferation of this learning platform requires the development of teacher creativity to choose and use it appropriately. Through their creativity, a teacher can choose online media and learning platforms appropriately as online learning media. However, the reality on the ground is that not all teachers have good ICT and online media mastery skills. Not even online media, even in contact with computers as a means of online learning some teachers do not have this knowledge. As the data obtained by the author at 03 Elementary School of Jakarta, of the 38 existing teachers who are 
proficient in using online media, only 8 are moderate, 15 are moderate, and the rest do not have knowledge of online media in learning.

The lack of teacher creativity is not an obstacle. The solution that we make is a solution that can solve the problem quickly, not having to go through a plan. So, we must prepare a strategy or method that is fast, agile, smart, and passionate. The strategy is the Agile Method, which is a strategy that prioritizes speed, collaboration, internet, and execution. As Muhammad Robith Subandi said, "Agile Software Development is a software development methodology based on an iterative process where 7 agreed rules and solutions are carried out with collaboration between each team in an organized and structured manner". (Adani, Muhammad Robith. 2020) Complete Description of Agile Methods in Software Development. Agile development is a software development model in the short term, which is then adapted quickly to cope with any changes. The most important value of Agile development is that it allows a team to make decisions quickly, with good quality and predictions, and has good potential to handle any changes. Adopting this, the researcher then made a research design to overcome the crisis in the implementation of online learning or BDR which had to be implemented quickly, without planning, but had good quality and predictions in dealing with a change. Agile development as Brewer says the following:

"Technical information \& Communication Technology for Development (ICTD) research refers to work by computer scientists and engineers to create appropriate ICT solutions to support social and economic development objectives. Critical challenges are not only to build contextually adapted ICT solutions but also to approaches for developing and deploying the innovative system in ways that are scalable and sustainable in the longer term (Brewer et al., 2005).

In this study, the researcher used the Agile method in a series of cycles, namely choosing the research area that became the focus (A) where the focus was on the state of the teachers at 03 Elementary School who experienced an internet-based information technology crisis to run online learning or e-learning, then researchers take action based on existing situations and conditions, namely rapid changes due to the Covid-19 pandemic by applying the methodology of the Agile Method (B), by making an idea framework guide (P), namely through a method or strategy by sharing knowledge. (Hayana, Syarif KM, 2019). From an Islamic perspective, sharing knowledge is highly recommended as stated in the hadith narrated by Ibn 'Abbas RA: The Prophet SAW said; "Whoever tries to put into practice what he knows, Allah will show him what he does not know. Sharing knowledge is also what makes difficult things easier (Myswati, 2019). As Allah says in Q.S. Al-Mujadilah verse 11 follows:

Means: "O you who believe! If it is said to you, "Give spaciousness in the assemblies," then make room for it, Allah will surely provide spaciousness for you. And when it is said, "Stand up," then stand up, Allah will raise (degrees) those who believe among you and 
those who are given knowledge by several degrees. And Allah is Accurate of what you do."

This verse proves that Islam strongly encourages the sharing of knowledge in forums and elevates the status of mankind through what they do, meaning that sharing knowledge can increase creativity. This is what motivated researchers to research by looking at cases that emerged in the era of the COVID-19 pandemic which came so quickly and suddenly, while in this emergency condition learning in schools, especially 03 Elementary School must continue. While the learning process cannot be face-to-face due to the Large-Scale Social Restrictions (PSBB) which requires learning to be done online or e-learning while learning service providers, especially teachers at 1103 Elementary School are not adequate due to the level of computer mastery and the use of online media as an online learning tool is still minimal or uneven and even some gaps can cause the online learning process to not work well, so the researcher who happens to be the Deputy in the Curriculum Sector, immediately takes a strategy to take action quickly, but must carefully, to form a team that can collaborate to help teachers who have not mastered ICT and online media for online learning by sharing knowledge. Through this knowledge sharing strategy, it is expected to be able to provide solutions quickly, enthusiastically, precisely, reflectable, and sustainably (Agile Development Method) in overcoming the crisis of the problem of implementing online learning through online media at 03 Elementary School, so that later all teachers at 03 Elementary School can quickly increase their creativity in online learning and can choose online media and online learning platforms appropriately, quickly, effectively, and efficiently. So that the implementation of online learning / online or e-learning runs smoothly.

\section{Literature Review Agile Method}

Agile Development is a method of developing software quickly with changing requirements that occur in a relatively short time. The main concept of Agile Development is application development and teamwork. Focus on application work by minimizing documentation. Teamwork in the form of 2 or more people working on one feature and intensive communication. Agile Development is in the form of literacy or iteration, the goal is to respond and deal with any changes flexibly, thereby reducing project time and achieving client satisfaction. Agile development practices are suitable for use on small-scale projects and are carried out by small teams. (Beon Intermedia, April 21, 2020).

The principles of the Agile Development Method became known as the Agile Manifesto. "The Agile Manifesto" (Hohl et al, 2018) consists of 12 main principles, namely:

a) Emphasizing the satisfaction of clients by making it a top priority in producing products early and sustainably. 
b) Accept any changes during the software development process even though it is in the final stages of development.

c) Produce products in the form of software that is made with a short period (2 weeks - 2 months), with proven quality.

d) There was a good cooperation process between the developer and the businessman during the project.

e) Build an environment that contains highly motivated people. To complete the project effectively and efficiently.

f) Direct communication is needed in the process of developing software, Software that works well and perfectly is a measure of project progress.

g) Agile methods can develop software on an ongoing basis from the support of parties such as sponsors, users, and developers themselves.

h) Technical excellence is a priority in software development using Agile methods.

i) Simplicity here is very important for Agile itself in maximizing an existing resource.

j) All needs in terms of architecture and software requirements are very dependent on the management of each development team.

k) Periodically, each development team conducts self-evaluation (reflection) to work more effectively and organize their work patterns, and simplicity is the most important thing in Agile Development.

l) Maximize existing resources.

Adopting the Agile Software Development Method, Matt Lemay in his book entitled "Agile for Everybody" (2019) states that the principles of the Agile Development Method are based on: Iterative and incremental development, a collaboration between crossfunctional teams, self-organization, adaptive planning, development, and evolutionary delivery, time boxes for iterative approaches, and encourage rapid and flexible responses to change. From the principles of the Agile Method above, the researcher takes the main focus to be applied in learning management, namely:

a) Accept all forms of change, for development.

b) There is a good collaboration process between interdisciplinary teams.

c) Build an environment that contains highly motivated people. To complete the project effectively and efficiently.

d) Direct communication is needed in the development process.

e) Periodically, each development team conducts self-evaluation (reflection) to work more effectively and adjust their work patterns. 


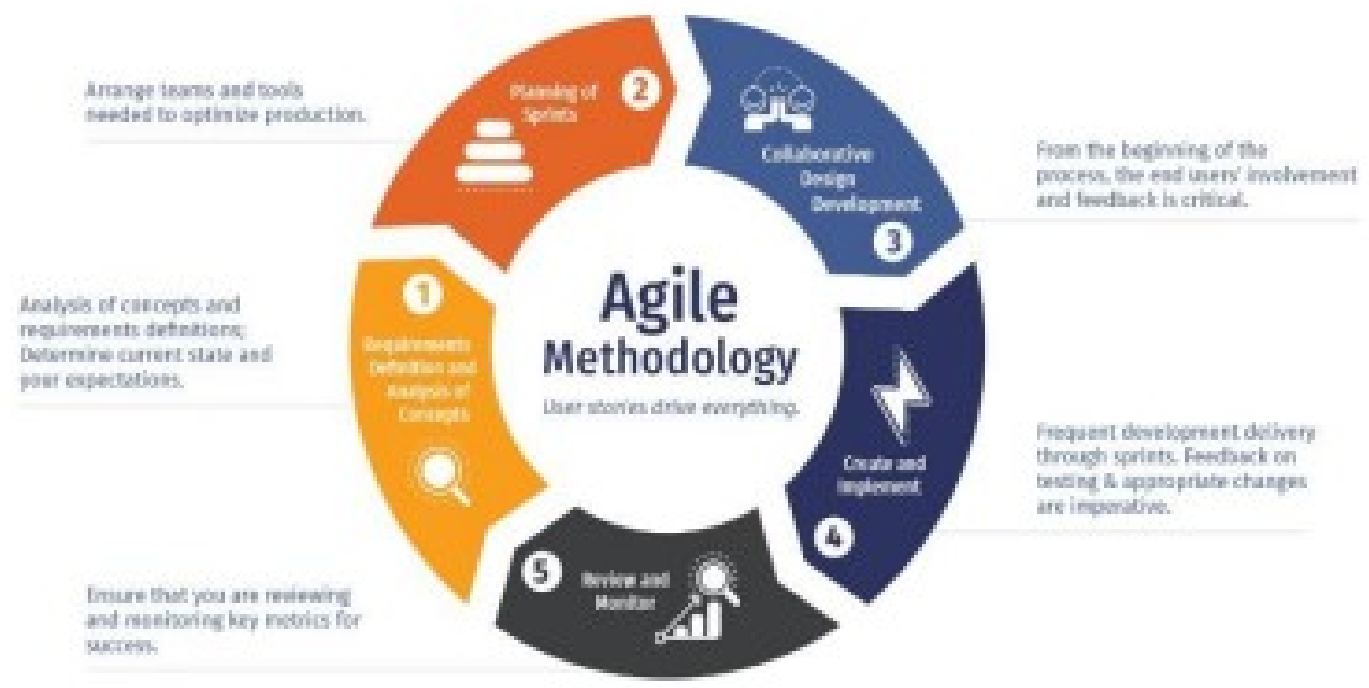

\section{Picture 1. The Agile Method}

Source: Agile and Lean Concepts for Teaching and Learning (David Parsons-Kathryn MacCallum, 2019).

From the overall theory of Agile Method according to experts, the researcher concludes that the relevant theory used in this study is using the theory of Allen (2012) which states that "Educational institutions are full of processes, and some of these might benefit from a more agile, adaptive, change-embracing approach. Agile processes are essentially iterative cycles of creation and reflection, where budgets and timescales are fixed, and quality is a given".

Allen (2012) also mentions that in the world of Agile theory it is appropriate to use in the field of education to measure exploration and development, a collaboration between ages, self-management, team planning, and fast and flexible response. These five elements will be used by researchers to measure how the application of Agile methods at 03 Elementary School through sharing knowledge to increase teacher creativity measured from various generations.

\section{Knowledge Sharing}

Knowledge sharing is a method or activity in knowledge management that is used to provide and disseminate knowledge, ideas, experiences, or skills from a person, department, organization, agency, or company to create a basic need for cooperation. 
Knowledge sharing is part of knowledge management to create ideas and innovations that will contribute to the sustainability of an organization. According to Chen (2001), knowledge sharing is interpersonal communication that involves communicating and receiving knowledge from others, and one of the main ways to transfer knowledge is like human interaction. Meanwhile, according to Lin (2007), knowledge sharing is a culture that involves social interaction in which employees exchange knowledge, experience, and skills (skills) through all departments or organizations. Furthermore, Subagyo (2007), knowledge sharing is a method or one of the steps in knowledge management that are used to provide opportunities for members of a group, organization, agency, or company to share their knowledge, techniques, experiences, and ideas. to other members. And according to Pasaribu (2009) knowledge sharing is a culture of social interaction, including the exchange of knowledge between employees, experience, and skills through entire departments or organizations, this creates a common basis for the need for cooperation.

With the principle of sharing knowledge, it is hoped that it can increase teacher creativity, especially in the era of the sudden and fast-paced COVID-19 pandemic. The most important thing in this strategy, we can reflect and evaluate it by conducting continuous monitoring. The advantage of this knowledge-sharing strategy is that there is a collaboration between teams, and it is carried out in a family way so that no one feels being patronized or patronized. This is expected to create a sense of comfort, enthusiasm, so that it is hoped that it can foster the creativity of teachers in dealing with situations, especially in the era of the COVID-19 pandemic. The benefit of sharing knowledge is the creation of new knowledge that can result in innovation, improve the skills of each member and reduce the risk of repeating mistakes that have been made.

From the whole theory mentioned above, there are indicators in Knowledge Sharing that can be used as a benchmark for success. According to Matzler (2008), the indicators used to measure the success of the implementation of knowledge sharing are as follows:

a) Embraided Knowledge. Knowledge related to conceptual skills and individual cognitive abilities through formal study (learning by studying). Example: conceptual skills and cognitive abilities.

b) Embodied Knowledge. Knowledge where the individual's body can carry out activities without verbal representation of a thought. Knowledge is formed in a person who comes from previous experience. Example: knowledge based on experience or learning by doing.

c) Encultured Knowledge. Affective and cognitive structures are used by organizational members to perceive, explain, evaluate and construct reality. This knowledge also includes the assumptions and beliefs used to derive new values and information. Example: mutual understanding, etc.

d) Embedded Knowledge. The collective form of knowledge is embedded in organizational routines, practices, values, norms, and shared beliefs. Example: company/agency-specific routines, procedures, etc. 
e) Encoded Knowledge. The knowledge that has been codified and explicit. Examples: books, work manuals, job descriptions, and others.

\section{Creativity Increase}

According to Vernon S. Gerlach \& Donald P. Ely in the book Teaching \& Media-A Systematic Approach (Arsyad, 2011: 3) which suggests that learning is a behavior change, while behavior is an observable action, in other words, behavior is an action. observable or the result of an observable action or actions. Furthermore, Abdillah (Aunurrahman, 2010: 35 ) concluded that learning is a conscious effort made by individuals in changing behavior, both affective and psychomotor to obtain certain goals (Kompri, 2016). Creativity is the ability to provide new ideas (not something that has not existed before) and apply them in problem-solving, creativity includes both aptitude characteristics such as fluency, flexibility, and originality in thinking and traits (non-aptitude), such as curiosity, love to ask questions, and always want to seek new experiences.

Based on the above, according to the researcher, creativity is possessed by an educator, especially a teacher as the frontline in education who is in direct contact with students so that these students can think critically, creatively, and innovatively. Teacher creativity is the ability of a teacher to obtain innovative new ideas that can be applied in the learning process to realize creative and innovative goals. In the Industrial Era 4.0, creativity must be developed by a teacher to face the challenges of change that come very quickly and suddenly. In particular, creativity in ICT is synonymous with the industrial era 4.0. If in an agency/company/organization there is a gap, namely a gap in the expertise to operate ICT, the strategy used is a knowledge sharing by developing Agile Development that prioritizes working fast, carefully, enthusiastically, the collaboration between teams, and can be done repeatedly and continuously through monitoring and evaluation. Knowledge sharing and discussion group forums will be able to develop ideas because each teacher can take experiences from other friends and can share their best experiences.

\section{Research Method}

This study uses a qualitative approach. Qualitative research is a humanistic research model, which places humans as the main subjects in social/cultural events (Suradika, 2020). The method used is a descriptive qualitative research method, where researchers examine a phenomenon that occurs in education that changes rapidly due to the COVID-19 pandemic which is carried out in-depth to study the background, circumstances, and interactions that occur. In this case, a phenomenon that occurs especially in the researcher's workplace, namely SDN CIPULIR 03, where during the COVID-19 pandemic, students must continue to carry out creative, fun, and not boring learning remotely online. In line with the 3 principles of Agile methods applied in education, namely problem identification, fast and agile 
execution, evaluation, and follow-up. By using 5 of the 12 Agile manifestos, namely: Accepting all forms of change for development, there is a good collaboration process between interdisciplinary teams, building an environment that contains highly motivated people. To be able to complete projects effectively and efficiently, direct communication is needed in the development process. Periodically each development team conducts selfevaluation (reflection) to work more effectively and regulate their work patterns. To get indepth data, this case study research researchers use a technique The approach used in this research is descriptive-analytic researchers use it to look for similarities/patterns of an event that appears which will then be analyzed into a theory.

\section{Findings and Discussion Findings}

03 Elementary School is located in the Cipulir village, Kebayoran Lama district, South Jakarta, precisely on Ciledug Raya St No 56 003/006. The location of 03 Elementary School is right in front of the Cipulir Village office. The school with an area of $1468 \mathrm{~m} 2$ is located in a quite strategic area. The environmental potential of this school includes good cooperative relations between the school and parents or guardians of students, adequate means of worship, namely the availability of a prayer room that can be used for religious activities, security is quite guaranteed because the school has a fence around it. a beautiful and comfortable environment for the implementation of learning. Facilities and infrastructure are quite complete for the implementation of learning. There are adequate local schools, there are computer labs and libraries that support the learning process.

The general description of the situation to be observed is the condition of teachers who vary in age and level of creativity related to ICT and adaptability in dealing with changes, the level of cooperation between teachers and education personnel in collaborating, as well as knowledge sharing activities carried out at 03 Elementary School. The initial observations that the researchers made were observations of teachers in dealing with situations of rapid change, in this case, due to the Covid-19 pandemic case which required online learning from home (BDR) which was closely related to ICT. Teacher creativity in ICT-based learning is the main focus of observation. Observations were then continued by surveying teachers' ability to use ICT. Followed by interviews with the principal and several teachers as samples about teacher creativity about ICT which is a gap for the implementation of creative and innovative learning processes during the COVID-19 pandemic or online learning. The interview guide is attached. Based on table 1. about the initial conditions of teachers in terms of the ability to create in using ICT, the researchers grouped them as follows: 


\section{Table 1. Teachers/Educational Personnel Based on the Level of Creativity in operating ICT for the Implementation of Learning}

\begin{tabular}{|c|l|c|}
\hline No. & \multicolumn{1}{|c|}{ Temuan } & Jumlah \\
\hline 1. & $\begin{array}{l}\text { Guru / tenaga Kependidikan kreatif menggunakan } \\
\text { TIK dalam pembelajaran sangat mahir }\end{array}$ & 11 \\
\hline 2. & $\begin{array}{l}\text { Guru / tenaga Kependidikan kreatif menggunakan } \\
\text { TIK dalam pembelajaran mahir }\end{array}$ & 8 \\
\hline 3. & $\begin{array}{l}\text { Guru / tenaga Kependidikan kreatif menggunakan } \\
\text { TIK dalam pembelajaran sedang }\end{array}$ & 8 \\
\hline 4. & $\begin{array}{l}\text { Guru / tenaga Kependidikan kreatif menggunakan } \\
\text { TIK dalam pembelajaran kurang }\end{array}$ & 8 \\
\hline 5. & $\begin{array}{l}\text { Guru / tenaga Kependidikan kreatif menggunakan } \\
\text { TIK dalam pembelajaran sangat kurang JUMLAH }\end{array}$ & 7 \\
\hline \multicolumn{2}{|c}{ JUM } \\
\hline
\end{tabular}

Source: Processed by researchers, 2021

From the table above as a result of observations and interviews with the principal and 6 teachers as representatives, namely 2 old teachers (50-60 years old), 2 middle school teachers (35-49 years old) and 65 young people (25-34 years old) found the following subfocus:

a) Sub Focus 1: There are obstacles faced by teachers in learning, especially in operating ICT skills as the main means of online learning. In the findings, it was found that teachers of a certain age were unable to operate ICT.

b) Sub Focus 2: The speed and enthusiasm of teachers in dealing with changes by the principles of the Agile method.

c) Sub Focus 3: In terms of increasing teacher creativity, it was found that older teachers on average have good learning creativity compared to younger ones, perhaps because of the experience factor. Unless their ICT creativity is weak. Meanwhile, young teachers have less creativity in learning but in ICT they are very good.

d) Sub Focus 4: Things that are usually done by teachers at 03 Elementary School, namely some teachers are generally old in age relying on or always asking for help from the young, especially in matters relating to ICT and the habit of discussions carried out by teachers in 1 team to solve problems.

\section{Discussion}

Based on the findings of data from observations and interviews, it was found that several educators lacked ICT skills which are the main means of learning today (online learning during the COVID-19 emergency) and in the future, the School Management Team 
of 03 Elementary School is led by the principal immediately took action, which the researchers processed according to the sub-focus described earlier, namely:

a) Sub Focus 1: The school management team of 03 Elementary School took action quickly in dealing with obstacles by the Agile Methodology in Education, namely: Analysis of ongoing problems carried out by the Curriculum Development Team, the Curriculum Development Team making quick strategies to overcome these problems, and the establishment of a Forum Group Discussion (FGD) facility as a forum for delivering opinions and evaluating performance.

b) Sub Focus 2: Knowledge Sharing action plan. Teams that collaborate, are highspirited, intelligent, careful, and easy to adapt to change then create a discussion group forum or Forum Group Discussion (FGD) in the internal team to discuss developments in learning creativity. They can share knowledge according to their abilities.

c) Sub Focus 3: Changes in teacher creativity in ICT-based learning. After the knowledge sharing activity through grouping and the high enthusiasm of the teachers, finally, there was a change, wherein group 1 which consisted of teachers who were old and failed in technology, began to operate ICT and had started to be independent. the middle group who are quicker to accept their knowledge have started to be creative by using applications on the internet, even in teaching teachers it has been seen that some make their learning videos, as well as interesting and more creative PowerPoints.

d) Sub Focus 4: After the action of implementing the program with a Knowledge Sharing strategy, the teachers seemed to be showing creativity in online learning, not only Whatsapp, but also being able to use the Zoom application with its features, making creative PPT, and even making learning videos and applications that are widely developed on the internet. This Knowledge Sharing Strategy activity can be carried out continuously and can be evaluated. The existence of a TEAM of experts in the TEAM of Curriculum Developer is very helpful in implementing the program.

\section{Conclusion and Recommendation}

Conclusion: From the data analysis described in chapter IV, the following conclusions can be drawn: Changes must occur to deal with changes, especially in the world of education, which is fast, so we must act quickly, critically, intelligently, adaptable, collaboratively, and enthusiastically. To make the right strategy, fast, smart, adaptable, and passionate in the face of rapid change, the Agile Method (Agile Methodology) is used which can quickly overcome these changes without going through planning, but through analysis making strategy action-reflection evaluation-making new strategies carried out by collaborative, high-spirited, intelligent, and adaptable teams. A new strategy that is effective and efficient in dealing with the rapid changes in the learning system at 03 Elementary 
School is a knowledge sharing from teachers who have more knowledge than other teachers or from the Expert Team. With the holding of a knowledge-sharing forum at 03 Elementary School in a structured and continuous manner, it is proven that there is an increase in teacher creativity at 03 Elementary School, where within 2 months the teachers who were previously unable to operate ICT became able too and more creative in organizing learning using ICT. One of the ways to increase teacher creativity is through knowledge sharing.

Recommendation: The agile method (Agile Methodology) should not only be limited to teachers and education personnel. Agile methods can also be applied in the classroom learning so that the learning process produces individuals who are creative, critical, passionate, innovative, exploratory, and adaptable in the face of changes that will always occur. For that, we need teachers who have mastered the Agile Method. Knowledge Sharing can also be applied in the classroom, where children who already have prior knowledge can share it with their friends through discussion group forums or peer tutorials. To foster creativity in children, creative teachers are needed, so this Knowledge Sharing strategy can be continued, perhaps even at a wider level, not only at the school level but also through clusters as a means of working group groups in the region.

\section{References}

Abdullah, R. (2017). Pembelajaran Dalam Perspektif Kreativitas Guru Dalam Pemanfaatan Media Pembelajaran. Lantanida Journal, 35. https://doi.org/10.22373/lj.v4i1.1866

Aleksa, T. (2019). Upaya meningkatkan kemampuan guru dalam menerapkan pembelajaran tematik melalui in house training di SDK Diller. Jurnal Serambi Akademica, 7(5), 612. https://doi.org/10.32672/jsa.v7i5.1517

Alexandra, J. (2018). Agile Development Methods. Journal of Chemical Information and Modeling (Vol. 53, Issue 9, pp. 1689-1699). https://sis.binus.ac.id/2017/05/08/agiledevelopment-methods/

Andayani, Dyah Darma, Fathahillah, \& Abdal, Nurul Mukhlisah. (2020). Penerapan elearning sebagai alternatif pembelajaran. peluang dan tantangan pengabdian kepada masyarakat yang inovatif di era kebiasaan baru, 228-236.

Darmadi, H. (2016). Tugas, peran, kompetensi, dan tanggung jawab menjadi guru profesional. Edukasi: Jurnal Pendidikan, 13(2), 161-174

Deda, Y. N. (2019). Workshop Media Animasi untuk Meningkatkan Kreativitas Guru di Kelurahan Kefamenanu Tengah. ETHOS, Jurnal Penelitian dan Pengabdian, 7(1), 70-76. https://doi.org/10.29313/ethos.v7i1.4151

Firmaiansyah, D. (2014). Pengaruh Berbagi Pengetahuan Terhadap Kinerja Karyawan Melalui Inovasi. Jurnal Ilmu Manajemen, 2(1), 128-139. 
Haryana, K. S. (2019). Penerapan agile development methods dengan framework scrum pada perancangan perangkat lunak kehadiran rapat umum berbasis Qr-Code. Jurnal Computech \& Bisnis, 13(2), 70-79.

Hastuti, R. A. (2018). Pemanfaatan metode agile ui prototyping dalam perancangan aplikasi e-learning perguruan tinggi. http://repository.untag-sby.ac.id/id/eprint/1220

Herdiana, B., et al., (2018). Penerapan Metode Integrasi Teileren-Poject pada Program Inovasi IPTEK dan Kreativitas Guru-Guru Elektronika Industri di SMKN 9 Kabupaten Garut dalam Kegiatan Workshop Aplikasi Mikrokontroller.Jurnal Pengabdian Kepada Masyarakat, 4(1), 41. https://doi.org/10.22146/jpkm.32696

Hohl, P., Klünder, J., van Bennekum, A., Lockard, R., Gifford, J., Münch, J., Stupperich, M., \& Schneider, K. (2018). Back to the future: origins and directions of the "Agile Manifesto" - views of the originators. Journal of Software Engineering Research and Development, 6(1). https://doi.org/10.1186/s40411-018-0059-z

Ibrahim, D. S., \& Suardiman, S. P. (2014). Pengaruh Penggunaan E-Learning Terhadap Motivasi Dan Prestasi Belajar Matematika Siswa Sd Negeri Tahunan Yogyakarta. Jurnal Prima Edukasia, 2(1), 66. https://doi.org/10.21831/jpe.v2i1.2645.

Johnson, C. (2020). Agile and lean concepts for teaching and learning: bringing methodologies from industry to the classroom. In Action Learning: Journal of Research and Practice (Volume 17, Issue 3). https://doi.org/10.1080/ 14767333.2020.1820673

Kamat, V. (2012). Agile manifesto in higher education. Proceedings - 2012 IEEE 4th International Conference on Technology for Education, T4E 2012, 231-232. https://doi.org/10.1109/T4E.2012.49

Malik, R. F., Fachrurrozi, M., Prabowo, R., \& Elakang, L. A. B. (2017). Menggunakan metode agile dengan konsep model-view-controller data access object. Buku Seminar Ilkom, 6569.

Miswaty (2019). Perilaku berbagi ilmu menurut pandangan islam dan manfaatnya dalam profesi akuntansi, Jurnal Ekonomi Dan Manajemen, 13(1), 29-38.

Mujakir, M. (2017). Kreativitas guru dalam pembelajaran IPA di sekolah dasar, Lantanida Journal, 3(1), 82. https://doi.org/10.22373/lj.v3i1.1443

Mulyati, Y. S. (2013). Pengembangan kreativitas guru dalam meningkatkan kualitas pendidikan, Journal of Chemical Information and Modeling, 53(9), 1689-1699.

Mustakim, M. (2020). Efektivitas pembelajaran daring menggunakan media online selama pandemi covid-19 pada mata pelajaran matematika. Al Asma: Journal of Islamic Education, 2(1), 1. https://doi.org/10.24252/asma.v2i1.13646

Oktiani, I. (2017). Kreativitas guru dalam meningkatkan motivasi belajar peserta didik. Jurnal Kependidikan, 5(2), 216-232. https://doi.org/10.24090/jk.v5i2.1939 
Purwanto, A., et al., (2020), Studi Eksploratif dampak pandemi covid-19 terhadap proses pembelajaran online di sekolah dasar, EduPsyCouns: Journal of Education, Psychology and Counseling, 2(1), 1-12. https://ummaspul.e-journal.id/Edupsycouns/ article/view/397

RI, P. (2020). PP Republik Indonesia Nomor 21 Tahun 2020, tentang Pembatasan Sosial Berskala Besar dalam rangka percepatan penanganan Corona Virus Disease, 2019 (COVID-Ig).

Setiarso, Bambang (2007). Penerapan knowledge management di organisasi. Ilmu komputer, Jakarta.

Subagya, K. A., Pratami, D., \& Hasibuan, M. A. (2019). Pengembangan Konten E-Learning Menggunakan Design Sprint Pada Mata Kuliah Manajemen Proyek, Jurnal Integrasi Sistem Industri, 6(2), 107-116.

Suradika, Agus.(2020). Metodologi Penelitian: Unversitas Muhammadiyah Jakarta.

Suri, N. (2019). Landasan Teori. Journal of Chemical Information and Modeling, 53(9), 16891699.

Yulisari, Veti. 2017. Pengaruh penerapan model pembelajaran treffinger terhadap peningkatan kreativitas belajar siswa pada materi menghiasi pribadi dengan berbaik sangka dan beramal saleh: Thesis, UIN Jakarta, Jakarta. 